\title{
MENGUNGKAP MATERI MUATAN PERATURAN PRESIDEN NOMOR 38 TAHUN 2015 TENTANG PERJANJIAN KERJASAMA PEMERINTAH DAN BADAN USAHA DALAM PENYEDIAAN INFRASTRUKTUR ${ }^{1}$
}

\author{
Ricca Anggraeni*, Indah Mutiara Sari \\ Fakultas Hukum Universitas Pancasila \\ J1. Srengseng Sawah, Jakarta Selatan, 12640 \\ riccaanggraeni@univpancasila.ac.id
}

\begin{abstract}
Since 2015, Indonesian government intensively did infrastructure development. Trillions is needed to comply the infrastructure development targets. But the government only capable to contribute 41 percent for financing, government finally opens some investment opportunities for business entities through the Public Private Partnership system. PPP is legalized through Presidential Regulation Number 38 of 2015. Based on Article 5 of that Presidential Regulation, the types of infrastructure in PPP are public facilities that affect the livelihood of many people. PPP's system is potentially caused some problems because of their comprehensive aspects, and their demand that infrastructure projects has to created profits. The Presidential Regulation No. 38 of 2015 concerning PPP also considered will "defeat" the provisions of the sectoral Law, which normatively should be, "the higher one defeats the lower one." This problem resolved through normative legal research methods.
\end{abstract}

Keywords: Payload Material; Presidential Regulation; Public Private Partnership; Infrastructure

\begin{abstract}
Abstrak
Sejak tahun 2015, pemerintah Indonesia terlihat gencar melakukan pembangunan infrastruktur, dan diperlukan biaya ribuan triliun memenuhi target pembangunan infrastruktur. Namun, Pemerintah hanya dapat berkontribusi sebesar 41 persen untuk pembiayaan, sehingga pemerintah akhirnya membuka peluang investasi melalui jalur Kerjasama Pemerintah dengan Badan Usaha (KPBU). KPBU saat ini dilegalisasi melalui Peraturan Presiden Nomor 38 Tahun 2015 tentang KPBU Dalam Penyediaan Infrastruktur. Berdasarkan Peraturan Presiden Nomor 38 Tahun 2015, jenis-jenis infrastruktur yang di KPBU kan ialah fasilitas publik yang menguasai hajat hidup orang banyak. KPBU berpotensi menimbulkan masalah karena aspek yang komprehensif, dan menuntut proyek infrastruktur mampu mencipta keuntungan. Melalui penelitian hukum doktriner, didapatkan bahwa terdapat kemungkinan bahwa KPBU yang diatur melalui Perpres Nomor 38 Tahun 2015 akan "mengalahkan" ketentuan dari Undang-Undang sektoral, padahal secara normatif, "yang lebih tinggi justru mengalahkan yang lebih rendah."
\end{abstract}

Kata Kunci: Materi Muatan; Peraturan Presiden; Kerjasama Pemerintah Badan Usaha; Infrastruktur

\footnotetext{
${ }^{1}$ Hasil penelitian ini didanai secara internal oleh Fakultas Hukum Universitas Pancasila, pada tahun 2018. Penelitian ini dilaksanakan dalam rangka pemenuhan kinerja penelitian Fakultas Hukum Universitas Pancasila Tahun Anggaran 2018.
} 


\section{A. Pendahuluan}

Dalam kurun waktu 4 (empat) tahun terakhir, Pemerintah Indonesia gencar melakukan pembangunan infrastuktur. Kegencaran ini diperlukan mengingat data dari International Institute for Management Development (IMD) yang menunjukkan bahwa pada tahun 2011 Indonesia berada pada peringkat 37 (tiga puluh tujuh) dari 59 (lima puluh sembilan) negara dengan titik lemah tingkat daya saing. Data ini menunjukkan bahwa perekonomian Indonesia tidak cukup kuat, yang disebabkan salah satunya oleh aspek infrastruktur (Maryaningsih, 2014).

Disadari betul jika upaya pembenahan kondisi infrastruktur menjadi kunci untuk mendukung pertumbuhan ekonomi dalam jangka panjang. Ini juga merujuk pada publikasi World Development Report yang dilakukan pada tahun 1994, yang menyatakan bahwa infrastruktur berperan penting dalam meningkatkan pertumbuhan ekonomi (Maryaningsih, 2014).

Demi mencapai pertumbuhan ekonomi, Pemerintah Indonesia menargetkan program pembangunan infrastruktur dengan berfokus pada infrastruktur ekonomi dan sosial yang ditujukan untuk peningkatan kebutuhan dasar dan konektivitas manusia, mulai dari air, listrik, energi, hingga transportasi (jalan raya, kereta api, pelabuhan, dan bandara) (Peraturan Presiden tentang Kerjasama Pemerintah dan Badan Usaha Dalam Penyediaan Infrastruktur, 2015). Pembangunan infrastruktur yang dilakukan untuk mewujudkan target itu membutuhkan anggaran yang tidak sedikit. Berdasarkan Rencana Pembangunan Jangka Menengah Nasional (RPJMN) 2015-2019, total Rp 4.796 triliun diperlukan untuk memenuhi target pembangunan infrastruktur (yang ditetapkan pemerintah) pada tahun 2019 (Widyastuti, 2018).

Namun, pemerintah (baik pusat dan daerah) dan perusahaan milik negara (BUMN) tidak dapat memenuhi kebutuhan anggaran itu, sehingga pemerintah membuka peluang investasi bagi badan usaha untuk ikut membangun infrastruktur melalui jalur
Kerjasama Pemerintah dengan Badan Usaha atau yang disebut KPBU.

KPBU dilegalisasi melalui Peraturan Presiden Nomor 38 Tahun 2015 tentang Kerjasama Pemerintah dan Badan Usaha Dalam Penyediaan Infrastruktur (Perpres No. 38 Tahun 2015). Menurut Perpres Nomor 38 Tahun 2015 pengertian dari KPBU adalah:

"kerjasama antara pemerintah dan Badan Usaha dalam Penyediaan Infrastruktur untuk kepentingan umum dengan mengacu kepada spesifikasi yang telah ditetapkan sebelumnya oleh Menteri/Kepala Lembaga/Kepala Daerah/BUMN/BUMD, yang sebagian atau seluruhnya menggunakan sumber daya Badan Usaha dengan memperhatikan pembagian risiko antara para pihak."

Pasal 5 Perpres Nomor 38 Tahun 2015 menyebutkan dengan jelas tentang jenis infrastruktur yang dapat dibangun dengan mekanisme KPBU, yaitu infrastruktur ekonomi dan sosial, yang kesemuanya merupakan fasilitas publik yang menguasai hajat hidup orang banyak.

Dikarenakan untuk memenuhi kebutuhan hidup orang banyak, kekhawatiran sesungguhnya dalam pembangunan infrastruktur melalui KPBU, ialah meminimalisasi risiko yang ditimbulkan dari pembangunan proyek untuk memenuhi kebutuhan masyarakat, dan aspek komersial yang harus dimiliki oleh proyek infrasruktur. Oleh karena itu, Pemerintah harus serius memperhatikan berbagai aspek dalam penyusunan Outline Bussines Case (OBC) yang menjadikan proyek infrastruktur itu layak untuk dilakukan, dan itu membutuhkan dasar legitimasi dari berbagai peraturan perundang-undangan yang menyentuh berbagai aspek dari pembangunan infrastruktur.

KPBU saat ini diatur melalui Perpres No. 38 Tahun 2015. Perpres menurut UU No. 12 Tahun 2011, merupakan jenis peraturan yang berada di bawah Peraturan 
Pemerintah. Dengan demikian, Perpres No. 38 Tahun 2015, memiliki kekuatan mengikat yang tidak lebih tinggi dibandingkan dengan Undang-Undang sektoral atau Peraturan Pemerintah.

Apabila menggunakan pendekatan teori norma hukum dari Hans Nawiasky, Perpres terkategori sebagai kelompok ke IV (verordnung and autonomie satzung), yang artinya berfungsi sebagai peraturan pelaksana dari formell gesetz (undangundang). Sedangkan, Perpres No. 38 Tahun 2015 merupakan aturan yang menjadi tulang punggung pelaksanaan KPBU di Indonesia dengan potensi memiliki singgungan terhadap Undang-Undang sektoral, mengingat jenis yang diinfrastrukturkan rerata sudah diatur menggunakan UndangUndang, seperti sektor transportasi, sumber daya air dan irigasi, telekomunikasi dan informatika, perumahan rakyat, dan kesehatan.

Mengenai infrastruktur, sebelumnya pernah dilakukan berbagai penelitian. Salah satunya ialah yang dilakukan oleh Sri Bagus Guritno dan Praptono Djunaedi yang membahas infrastruktur ketika diatur dengan Perpres No. 67 Tahun 2005, dengan tujuan untuk melakukan identifikasi atas hambatanhambatan yang dihadapi proyek-proyek yang berskema KPS (Guritno, 2012).

Di penelitian ini mengungkap suatu kebenaran mengenai materi muatan dari Perpes No. 38 Tahun 2015 yang mengatur KPBU. Materi muatan yang diatur dalam Perpres ini berpotensi akan "mengalahkan" ketentuan dari Undang-Undang sektoral, padahal secara normatif, Perpres berkedudukan lebih rendah. Seperti yang diketahui berdasarkan jenis dan hierarki peraturan perundang-undangan di Indonesia, Perpres secara hierarki berada di bawah Peraturan Pemerintah yang merupakan peraturan pelaksana dari Undang-Undang. Meskipun, Perpres dapat dibentuk dengan materi muatan untuk menyelenggarakan kekuasaan pemerintahan, namun berdasarkan hierarkinya tetap saja berada di bawah Undang-Undang. Dengan demikian, pertanyaan yang timbul ialah mengenai materi muatan Perpres No. 38 Tahun 2015 tentang KPBU, apakah memang merupakan materi muatan Perpres atau materi muatan undang-undang? dan Apakah terjadi penundukkan norma dari Undang-Undang sektoral terhadap Perpres No. 38 Tahun $2015 ?$

Melalui penelitian ini, didapatkan suatu jawaban mengenai materi muatan dari Perpes No. 38 Tahun 2015, dan mendorong agar infrastruktur dipahami sebagai masalah yang harus disolusikan melalui pembentukan Undang-Undang. Mengingat, permasalahan yang mengiringi pembangunan infrastruktur sangat komprehensif. Oleh karena itu, agar mampu memberikan seluruh pemahaman dalam penelitian ini, konstruksi dari penelitian ini terdiri dari 3 (tiga) bagian. Bagian pertama merupakan bagian pendahuluan yang yang didalamnya terdapat permasalahan dari penelitian ini. Bagian berikutnya yaitu Metode Penelitian, yaitu bagian yang menjelaskan proses pencarian dalam penelitian ini sehingga menemukan jawaban atas permasalahan. Sedangkan bagian kedua merupakan hasil Penelitian dan hnalisis. Di bagian ini diuraikan hasil elaborasi dari doktrin dan kondisi empiris. Bagian terakhir dari penelitian ini simpulan dan referensi.

\section{B. Metode Penelitian}

Beranjak dari permasalahan penelitian ini, metode yang digunakan untuk mencari kebenaran ialah metode penelitian doktrinal. Metode ini digunakan untuk mengetahui dan membuktikan mengenai materi muatan Perpres No. 38 Tahun 2015, tentu untuk ini pendekatan yang digunakan ialah peraturan perundang-undangan dan konsep.

Pendekatan konsep yang digunakan untuk menjawab permasalahan kedua ialah hierarki dari jenis peraturan perundangundangan di Indonesia yang menganut asas lex superiori derogate lex inferiori. Melalui asas ini, jenis peraturan perundangundangan dengan hierarki yang lebih tinggi tentu mengalahkan jenis peraturan perundang-undangan yang hierarkinya lebih rendah. Pendekatan ini diperlukan karena 
yang dipertanyakan ialah adanya pelanggaran asas lex superior derogate legi inferior dalam implementasi Perpres No. 38 Tahun 2015. Dengan demikian, data yang lebih dibutuhkan dalam penelitian ini ialah data sekunder dengan metode analisis yang kualitatif.

\section{Hasil dan Pembahasan}

\section{Peraturan Presiden dalam Sistem Peraturan Perundang-Undangan di Indonesia}

Hamid S. Attamimi dalam disertasinya yang diringkas oleh Irwan Yulianto dalam artikel yang berjudul "Peranan Keputusan Presiden Republik Indonesia Dalam Penyelenggaraan Pemerintahan Negara", menyatakan bahwa "Presiden memiliki kekuasaan pengaturan yang bersumber dari ketentuan-ketentuan pasal Undang-Undang Dasar Negara Republik Indonesia Tahun 1945, yaitu Pasal 4 ayat (1), Pasal 5 ayat (1) dan ayat (2), yang disebut dengan Keputusan Presiden (Yulianto, 2014).

Istilah Keputusan Presiden pada rezim Undang-Undang No. 10 Tahun 2004 diganti dengan Peraturan Presiden. Undang-Undang No. 10 Tahun 2004 tentang Pembentukan Peraturan Perundang-undangan saat ini telah digantikan oleh Undang-Undang No. 12 Tahun 2011. Latar belakang berubahnya nomenklatur Keputusan Presiden menjadi Peraturan Presiden ialah agar sifat dari produk hukumnya bersifat umum, bukan individual. Menurut Jimly Asshiddiqie, perbedaan antara keputusan (beschikking) dengan peraturan (regeling), ialah keputusan (beschikking) selalu bersifat individual dan kongkrit (individual and concrete), sedangkan peraturan (regeling) selalu bersifat umum dan abstrak (general and abstract) (Asshiddiqie, 2006).

Selain itu, Hamid S. Attamimi dalam disertasinya menjelaskan mengenai istilah keputusan yang dalam ketatanegaraan sama dengan istilah besluit. Besluit memiliki arti untuk menunjukkan "pernyataan kehendak dari instansi pemerintah dan pembuat perundang-undangan.” Ketika menggunakan istilah Keputusan, bisa jadi itu bersifat mengatur atau menetapkan, sehingga akan terjadi dualism pengaturan dengan jenis Keputusan. Menghindari hal yang demikian, dipilihlah suatu kepastian dengan menegaskan bahwa istilah Keputusan yang bersifat mengatur digunakanlah nomenklatur "peraturan". Sedangkan, istilah keputusan tetap digunakan untuk yang bersifat penetapan saja.

Berdasarkan Pasal 7 Undang-Undang No. 12 Tahun 2011, Peraturan Presiden merupakan jenis peraturan perundangundangan yang hierarkinya berada di bawah Peraturan Pemerintah. Artinya, Peraturan Presiden memiliki kekuatan hukum mengikat yang tidak lebih tinggi dari Peraturan Pemerintah. Akan tetapi Peraturan Presiden dapat memiliki kekuatan hukum yang kuat, jika Peraturan Presiden dibuat oleh Presiden atas inisiatif dan prakarsa sendiri untuk melaksanakan UndangUndang.

Hal tersebut dapat dilihat melalui ketentuan Pasal 13 Undang-Undang No. 12 Tahun 2011 yang mengatur mengenai materi muatan Peraturan Presiden. Materi muatan Peraturan Presiden merupakan materi yang diperintahkan untuk dibuat oleh UndangUndang secara langsung, materi untuk melaksanakan peraturan pemerintah, dan materi untuk melaksanakan penyelenggaraan kekuasaan pemerintah. Dari materi muatan ini, Peraturan Presiden yang dibuat oleh Presiden mengandung dua makna. Pertama, Peraturan Presiden dibentuk oleh Presiden atas inisiatif dan prakarsa sendiri untuk melaksanakan Undang-Undang. Kedua, maksud pembentukan Peraturan Presiden ditujukan untuk mengatur materi muatan yang diperintahkan oleh Peraturan Pemerintah.

Secara konsep, Peraturan Presiden diartikan sebagai "peraturan perundangundangan yang ditetapkan oleh Presiden untuk menjalankan perintah peraturan perundang-undangan yang lebih tinggi atau dalam menyelenggarakan kekuasaan pemerintahan." (Attamimi, 1990) Dengan demikian, Peraturan Presiden dapat menjadi 
jenis peraturan yang bersifat mandiri dengan melakukan pengaturan secara langsung berdasar pada ketentuan Undang-Undang Dasar, karena tidak terikat pada delegasian dari Undang-Undang ataupun Peraturan Pemerintah.

Dengan berdasar pada penjelasan di atas, dapat dilihat bahwa pembentukan Peraturan Presiden dapat bersumber dari kewenangan atribusi. Maksud dari kewenangan atribusi adalah pemberian kewenangan dari Undang-Undang Dasar (Grondwet) atau Undang-Undang (wet) kepada suatu lembaga negara atau pemerintah untuk membentuk peraturan perundang-undangan (Indrati, 2007). Ridwan HR menjelaskan bahwa wewenang yang diperoleh secara atribusi bersifat asli berasal dari peraturan perundang-undangan. Dengan kata lain, organ pemerintahan memperoleh kewenangan secara langsung dari redaksi pasal tertentu dalam peraturan perundang-undangan (Hadjon, 1998).

Kewenangan pembentukan Peraturan Presiden juga dapat berasal dari peraturan perundang-undangan yang lebih tinggi hierarkinya, dalam konteks ini ialah Undang-Undang dan Peraturan Pemerintah. Kewenangan itu disebut dengan kewenangan delegasi. Pengertian dari delegasi adalah kewenangan dalam membentuk peraturan perundang-undangan yang dilakukan oleh peraturan perundangundangan yang lebih tinggi kepada peraturan perundang-undangan yang lebih rendah, baik pelimpahan dinyatakan dengan tegas maupun tindakan (Hadjon, 1998).

\section{Pengaturan KPBU melalui Jenis Peraturan Presiden}

Kerjasama Pemerintah dan Badan Usaha atau yang biasanya disebut KPBU merupakan Kerjasama antara Pemerintah dan Badan Usaha dalam penyediaan infrastruktur untuk kepentingan umum dengan mengacu kepada spesifikasi yang telah ditetapkan sebelumnya oleh Menteri/Kepala Lembaga/Kepala Daerah/BUMN/BUMD, yang sebagian atau seluruhnya menggunakan sumber daya
Badan Usaha dengan memperhatikan pembagian risiko antara para pihak (Peraturan Presiden tentang Kerjasama Pemerintah dan Badan Usaha Dalam Penyediaan Infrastruktur, 2015) .

KPBU telah hadir di Indonesia sejak tahun 2005 dengan nama kerjasama pemerintah dan badan usaha atau yang sering disebut dengan KPS, legalitas atas KPS ini jelas diatur dengan Peraturan Presiden No. 67 Tahun 2005. Secara substansial, peraturan presiden mengenai KPS muncul hanya untuk mengakomodasi proyek-proyek infrastuktur tertentu seperti, bandara, pelabuhan, jalur kereta api, jalan, penyediaan air bersih/sistem pengairan, air minum, air limbah, limbah padat, informasi dan komunikasi teknologi, ketenagalistrikan dan minyak gas (Kementrian Koordinator bagian Perekonomian, 2010).

Harus diakui bahwa eksistensi dari KPS pada kurun waktu 5 (lima) tahun pertama, tidaklah mendapat respon yang baik dari para badan usaha dan masyarakat. Sebelumnya, KPS atau KPBU (saat ini) dikenal dengan nomenklatur Public Private Partnership (PPP). Artinya, KPBU memang berasal dari embrio PPP yang kurang direspon dan tidak diminati oleh pihak swasta (Rifai, 2014). Kurangnya peminatan itu dikarenakan regulasi yang tidak menjelaskan mengenai ranah peraturanperaturan terkait (lintas sektoral) maupun di tingkat daerah mengacu pada sektor/jenis kegiatan (Rifai, 2016), serta akibat oleh carut-marutnya sinkronisasi peraturan dan birokasi. Salah satu jalan keluarnya, ialah dibutuhkan kedinamisan norma hukum untuk menarik minat swasta di dalam pembangunan penyediaan infrastruktur. Progresifitas legislator dibutuhkan untuk membuat sistem KPBU yang mulai digandrungi oleh badan-badan usaha, masyarakat bahkan pemerintah itu sendiri. Dengan demikian, dapat dinyatakan bahwa konsep KPBU yang saat ini digunakan dalam proyek infrastruktur menggeser mayoritas pembiayaan dari Pemerintah kepada pihak swasta untuk meminimalisasi biaya pemeliharaan, peningkatan kualitas 
pelayanan, efisiensi terhadap ketertinggalan teknologi, risiko finansial, maupun dalam meningkatkan kapasitas pengelola (Indera, 2011).

KPBU yang berdasar pada Perpres No. 38 Tahun 2015 didorong untuk memperhatikan risiko di antara para pihak. Dengan alokasi risiko tersebut, KPBU merupakan mekanisme untuk membangun infrastuktur guna memajukan laju ekonomi, meningkatkan kesejahteraan masyarakat dan menyediakan fasilitas publik yang layak, dengan skema pendanaan alternatif yang diharapkan dapat menyediakan layanan infrastruktur dengan lebih efisien.

Layanan penyediaan infrastruktur yang dapat menggunakan mekanisme KPBU, menurut Pasal 5 Perpres No. 38 Tahun 2015 adalah infrastruktur ekonomi dan infrastruktur sosial. Dari berbagai jenis infrastruktur yang ditawarkan melalui skema $\mathrm{KPBU}$, dapat diketahui memiliki aspek kepentingan umum. Selain berdasarkan pada Perpres No. 38 Tahun 2015, terdapat beberapa peraturan yang mengatur mengenai KPBU, diantaranya Permen Perencanaan Pembangunan Nasional/Kepala Badan Perencanaan Pembangunan Nasional Republik Indonesia No. 4 Tahun 2015 tentang Tata Cara Pelaksanaan Kerjasama Pemerintah Dengan Badan Usaha Dalam Penyediaan Infrastruktur, dan Perka Lembaga Kebijakan Pengadaan Barang/Jasa Pemerintah No. 19 Tahun 2015 tentang Tata Cara Pelaksanaan Pengadaan Badan Usaha Kerja Sama Pemerintah Dengan Badan Usaha Dalam Penyediaan Infrastruktur.

\section{Mengungkap Materi Muatan Peraturan Presiden Nomor 38 Tahun 2015 tentang Perjanjian Kerjasama Pemerintah dan Badan Usaha Dalam Penyediaan Infrastruktur}

Di RPJMN telah dinyatakan bahwa pembangunan infrastruktur menjadi salah satu agenda besar dalam pembangunan Indonesia untuk kesejahteraan rakyat dan prioritas pembangunan nasional (Keliat, n.d.). Dengan demikian, pemerintah menyadari betul bahwa pembangunan infrastruktur yang memadai dan berkualitas menjadi satu keharusan untuk mendukung proses pembangunan secara menyeluruh (Keliat, n.d.). Infrastruktur itu sendiri dapat dibedakan jenisnya menjadi infrastruktur ekonomi seperti jalan, jembatan, pengolahan air minum dan sarana infrastruktur fisik lainnya, dan infrastruktur sosial seperti layanan kesehatan, pendidikan, lembaga pemasyarakatan dan layanan sosial lainnya. Infrastruktur ekonomi merupakan "asset fisik yang menyediakan jasa dan digunakan dalam produksi dan konsumsi final meliputi public utilities, public works, serta sektor transportasi." (Pamungkas, n.d.) Sedangkan infrastruktur sosial merupakan "asset yang mendukung kesehatan dan keahlian masyarakat meliputi pendidikan, kesehatan, serta untuk rekreasi." (Pamungkas, n.d.) Secara normatif, infrastruktur menurut Pasal 1 angka (4) merupakan "fasilitas teknis, fisik, sistem, perangkat keras, dan lunak yang diperlukan untuk melakukan pelayanan kepada masyarakat dan mendukung jaringan struktur agar pertumbuhan ekonomi dan sosial masyarakat dapat berjalan dengan baik."

Mekanisme KPBU dalam penyediaan infrastruktur ternyata menarik banyak pihak sebagai suatu sistem kelembagaan dengan dasar perjanjian. Dikatakan sistem, karena para pihak saling berkaitan dan berinteraksi dalam suatu proyek infrastruktur dengan mekanisme KPBU. Apabila dirunut secara normatif, maka pihak yang terlibat (berkepentingan) antara lain Penanggung Jawab Proyek Kerjasama (selanjutnya disebut PJPK).

Berdasarkan bunyi ketentuan Pasal 1 angka (3) PJPK merupakan "Menteri/Kepala Lembaga/Kepala Daerah, atau Badan Usaha Milik Negara/Badan Usaha Milik Daerah sebagai penyedia atau penyelenggara infrastruktur berdasarkan peraturan perundang-undangan." Masing-masing pejabat itu dapat mendelegasikan kewenangannya kepada pihak yang dapat mewakili kementerian/lembaga/pemerintah daerah yang ruang lingkup, tugas, dan tanggung jawabnya meliputi sektor 
infrastruktur sesuai dengan ketentuan peraturan perundang-undangan. PJPK memiliki peran yang penting dalam hal pengembalian investasi yang dapat berbentuk tariff, pembayaran ketersediaan layanan.

Selain PJPK, pihak yang juga berperan penting dalam KPBU ialah Simpul KPBU yang melekat pada unit kerja yang sudah ada di lingkungan Kementerian/Lembaga/Daerah atau unit kerja baru yang dibentuk dalam lingkungan Kementerian/Lembaga/Daerah. Simpul KPBU berperan penting pada tahap manajemen Pelaksanaan Perjanjian KPBU untuk membantu PJPK mengawasi jalannya pelaksanaan KPBU sesuai dengan yang telah disepakati dalam perjanjian KPBU.

Selain itu, masih terdapat lembagalembaga yang ikut berperan dalam proyek yang KPBU antara lain Kementerian Sektoral, yang berperan dalam mengatur kebijakan di sektor, termasuk penyusunan rencana induk nasional, dan penerbitan perizinan sesuai dengan kewenangannya, Kementerian Perencanaan Pembangunan Nasional/BAPPENAS, Kementerian Koordinator Bidang Perekonomian/Komite Percepatan Penyediaan Infrastruktur (KPPIP), Kementerian Keuangan, Kementerian Agraria dan Tata Ruang/Badan Pertanahan Nasional (BPN), Badan Koordinasi Penanaman Modal (BKPM), Lembaga Kebijakan Pengadaan Barang/Jasa Pemerintah (LKPP), Badan Usaha Penjaminan Infrastruktur (BUPI)/PT Penjaminan Infrastruktur Indonesia (PT PII), dan PT Sarana Multi Infrastruktur (SMI) yang dapat berperan sebagai Badan Penyiapan dalam pendampingan dan/atau pembiayaan kepada PJPK.

Menyadari banyaknya pihak yang terlibat di dalam pembangunan infrastruktur, menunjukkan bahwa perkembangan sistem KPBU di Indonesia signifikan. Ini juga dapat dilihat dari berbagai peraturan perundang-undangan yang mengatur tentang KPBU. Kompleksitas keterkaitan antar sektor dan berbagai regulasi, sesungguhnya memberikan signal yang kuat bahwa harus dibentuk satu peraturan yang dapat bertindak sebagai umbrella act untuk mengakomodasi berbagai peraturan perundang-undangan yang mengatur tentang KPBU.

Rekomendasi itu terbit, dengan mengingat peraturan yang mengakomodasi kebutuhan KPBU saat ini hanyalah berupa Peraturan Presiden. Perpres menurut Undang-Undang No. 12 Tahun 2011 memiliki kekuatan hukum sebagai peraturan pelaksana.

Selain itu, apabila dielaborasi dengan materi muatan Peraturan Presiden sebagaimana ditentukan melalui Pasal 13 Undang-Undang Nomor 12 Tahun 2011, maka Peraturan Presiden berfungsi untuk melaksanakan ketentuan Undang-Undang dan penyelenggaraan kekuasaan pemerintahan. Oleh karena itu, tidak heran apabila terdapat bunyi ketentuan UndangUndang yang langsung mendelegasikan ke Peraturan Presiden yang dapat segera dibentuk tanpa harus menunggu dibentuknya Peraturan Pemerintahnya terlebih dahulu. Ini pulalah yang disinyalir sebagai sebab ditemukannya ketidaksinkronan antara ketentuan yang terdapat di dalam Peraturan Pemerintah dengan Peraturan Presiden.

Selain Perpres No. 38 Tahun 2015, Peraturan Presiden yang dibentuk untuk menyelenggarakan kekuasaan pemerintahan ialah Peraturan Presiden Republik Indonesia Nomor 3 Tahun 2016 tentang Percepatan Pelaksanaan Proyek Strategis Nasional. Hal itu dapat dilihat dari bagian Mengingat Peraturan Presiden itu yang memuat Pasal 4 ayat (1) Undang-Undang Dasar Negara Republik Indonesia Tahun 1945. Peraturan Presiden semacam itulah yang menurut Hamid S. Attamimi, "sisa", yaitu sisa dari materi muatan yang tidak dapat diatur melalui Undang-Undang atau bukan materi muatannya Undang-Undang.

Hanya saja dengan perkembangan materi muatan Undang-Undang saat ini sebagaimana diatur melalui Pasal 10 Undang-Undang Nomor 12 Tahun 2011 tentang Pembentukan Peraturan Perundang- 
undangan, materi muatan Peraturan Presiden yang menurut Hamid S. Attamimi "sisa" itu tidak akan ada lagi, karena Undang-Undang dapat memuat apapun dengan argumentasi untuk memenuhi kebutuhan hukum masyarakat.

Kembali pada objek penelitian ini yaitu Peraturan Presiden Nomor 38 Tahun 2015 tentang Kerjasama Pemerintah dan Badan Usaha Dalam Penyediaan Infrastruktur, ini merupakan Peraturan Presiden yang dibentuk untuk melaksanakan penyelenggaraan kekuasaan pemerintahan. Apabila melihat pada konsiderans Peraturan Presiden ini, maka tidak terlihat sebenarnya mengenai kekuasaan pemerintahan itu, justeru yang terlihat ialah alasan untuk meningkatkan perekonomian nasional, menyejahterakan masyarakat, dan meningkatkan daya saing Indonesia dalam persaingan global, serta untuk mempercepat pembangunan infrastruktur, menciptakan iklim investasi yang dapat mendorong keikutsertaan badan usaha dalam penyediaan infrastruktur dan layanan berdasarkan prinsip-prinsip usaha yang sehat, melindungi dan menjaga kepentingan konsumen, masyarakat, dan badan usaha secara berkeadilan. Alasan-alasan itu menurut peneliti bukan dalam ranah materi muatan Peraturan Presiden, tetapi ranah UndangUndang. Ditambah dengan ranah implementasi Perpres No. 38 Tahun 2015 yang sangat membutuhkan peraturan pendukung, baik dalam jenis Peraturan Menteri maupun Peraturan Badan atau Peraturan Kepala Lembaga. Ini menunjukkan bahwa sebenarnya banyak sekali singgungan titik koordinasi yang dibutuhkan untuk mengimplementasikan mekanisme KPBU di dalam penyediaan infrastruktur.

Belum lagi jika mengingat jenis infrastruktur yang dapat diskemakan melalui KPBU, seperti transportasi, jalan, air minum, pengelolaan limbah, pengelolaan sampah, telekomunikasi, listrik, pendidikan, kesehatan, sarana dan prasarana olahraga dan kesenian, pariwisata, perumahan, bahkan Lembaga Pemasyarakatan
(Peraturan Presiden tentang Kerjasama Pemerintah dan Badan Usaha Dalam Penyediaan Infrastruktur, 2015).

Mengenai pemenuhan kebutuhan umum masyarakat, peneliti merujuk pada penelitian yang dilakukan oleh British Columbia's pada tahun 2009 yang telah melakukan penelitian mengenai kebutuhan hukum sipil terhadap 15 (lima belas) negara diantaranya yaitu Inggris dan Wales, Canada, New South Wales, New Zealand, Scotland, serta 9 (sembilan) negara bagian Amerika Serikat. Dari hasil survey tersebut, BC menyimpulkan bahwa dari berbagai negara yang diambil datanya, kebanyakan orang menghadapi masalah hukum dengan tipe yang sama (McEown, 2009). Masalah kebutuhan utama yang tidak terpenuhi dan ditemui di 15 (lima belas) negara yang disurvei ialah mengenai perumahan, kesehatan (termasuk soal disabilitas dan kesehatan mental), pekerjaan, pendidikan, pajak, keluarga, konsumen, transportasi dan hak asasi lainnya (McEown, 2009).

Dari hasil penelitian itu dapat dilihat, bahwa masalah transportasi, kebutuhan, pendidikan dan perumahan merupakan kebutuhan yang dibutuhkan oleh masyarakat. Pemenuhan kebutuhan itu harus dilakukan agar tidak memicu masalah lain dan itu, tentu membutuhkan campur tangan negara melalui instrument hukum agar terdapat proses yang adil di dalam memenuhi kebutuhan tersebut. Itu yang menjadi sebab munculnya konsep kebutuhan hukum masyarakat, untuk dipenuhi oleh instrument hukum atau norma negara yang memberikan perlindungan dan jaminan bagi masyarakat.

Dikarenakan jenis infrastruktur yang dapat di KPBU kan merupakan jenis untuk memenuhi kebutuhan umum masyarakat, maka terdapat berbagai peraturan perundang-undangan yang harus dikaji untuk memastikan bahwa mekanisme KPBU yang akan dilakukan sah berdasarkan ketentuan hukum yang berlaku di Indonesia.

Sebagai contoh untuk penelitian ini ialah KPBU yang dilaksanakan untuk penyediaan proyek infrastruktur jalan tol. Di 
dalam proyek ini, PJPK di dalam menyusun Studi Pendahuluan dan Studi Kelayakan harus mengkaji Undang-Undang No. 38 Tahun 2004 tentang Jalan, Peraturan Pemerintah (PP) No. 15 Tahun 2005 tentang Jalan Tol sebagaimana telah diubah terakhir dengan Peraturan Pemerintah No. 43 Tahun 2013, Peraturan Pemerintah No. 34 Tahun 2006 tentang Jalan, Peraturan Presiden No. 38 Tahun 2015 dan Undang-Undang No. 2 Tahun 2012 tentang Pengadaan Tanah untuk Kepentingan Umum. Belum lagi Undang-Undang tentang RPJP-RPJMN, dan peraturan lain dalam level Peraturan Menteri atau Badan atau Kepala Lembaga yang bersifat teknis untuk menentukan tata cara, seperti Tata Cara Pelaksanaan Kerjasama Pemerintah Dengan Badan Usaha Dalam Penyediaan Infrastruktur.

Jika dibandingkan dengan proyek infrastruktur di bidang kelistrikan, PJPK atau pemrakarsa harus merujuk pada Undang-Undang No. 30 Tahun 2009 tentang Ketenagalistrikan, Peraturan Pemerintah No. 1 Tahun 2008 tentang Investasi Pemerintah, Peraturan Pemerintah Nomor 23 Tahun 2014 tentang Perubahan Atas Peraturan Pemerintah Nomor 14 Tahun 2012 tentang Kegiatan Usaha Penyediaan Tenaga Listrik, Peraturan Presiden No. 78 Tahun 2010 tentang Penjaminan Infrastruktur Dalam Proyek Kerjasama Pemerintah dengan Badan Usaha yang dilakukan melalui Badan Usaha Penjaminan Infrastruktur, ada juga Peraturan Pemerintah No. 50 Tahun 2007 tentang Tata Cara Pelaksanaan Kerjasama Daerah.

Melihat hal tersebut, dapat dinyatakan bahwa dalam pelaksanaan KPBU bersinggungan dengan berbagai peraturan perundang-undangan, termasuk dalam jenis Undang-Undang. Dengan demikian, KPBU yang diatur di dalam Perpres No. 38 Tahun 2015 mengatur tentang pelaksanaan KPBU, sedangkan apabila dikontestasikan dengan jenis infrastruktur, maka sebenarnya ada halhal yang "mengalah" dengan ketentuan Peraturan Presiden tentang KPBU.

Dari ketentuan-ketentuan yang tertuang dalam Perpres No. 38 Tahun 2015, isi ketentuan berpotensi dan berpeluang mengalahkan ketentuan yang tertuang dalam Undang-Undang sektoral, ketika hal yang diatur dalam Undang-Undang tersebut, masuk dalam lingkaran yang di KPBU kan. Meskipun ini baru potensi dan peluang, bukan merupakan hal yang tabu bagi pembentuk Undang-Undang untuk mengkonsepkan tentang KPBU ini. Di dalam konsepsi ini akan terlihat rumusan masalah yang dihadapi oleh penyediaan infrastruktur dengan mekanisme KPBU.

Setelah ini dilakukan, baru terlihat sasaran yang akan diwujudkan dengan RUU tentang KPBU ini. Dari sinilah dapat dirumuskan politik hukum arah dan jangkauan pengaturan RUU KPBU, sehingga dapat terlihat bahwa KPBU ini memang layak menjadi materi muatan Undang-Undang.

\section{Simpulan}

Materi muatan Perpres No. 38 Tahun 2015 tentang KPBU mengatur secara konteks untuk pelaksanaan KPBU. Ketentuan Perpres No. 38 Tahun 2015 ini berpotensi dan berpeluang mengalahkan ketentuan yang tertuang dalam UndangUndang sektoral, ketika hal yang diatur dalam Undang-Undang tersebut, masuk dalam lingkaran yang di-KPBU-kan. Melihat pada konsiderans Peraturan Presiden ini, tidak terlihat mengenai kekuasaan pemerintahan itu, justeru yang terlihat ialah alasan untuk meningkatkan perekonomian nasional, menyejahterakan masyarakat, dan meningkatkan daya saing Indonesia dalam persaingan global, serta untuk mempercepat pembangunan infrastruktur, menciptakan iklim investasi yang dapat mendorong keikutsertaan badan usaha dalam penyediaan infrastruktur dan layanan berdasarkan prinsip-prinsip usaha yang sehat, melindungi dan menjaga kepentingan konsumen, masyarakat, dan badan usaha secara berkeadilan. Alasanalasan itu menurut peneliti bukan dalam ranah materi muatan Peraturan Presiden, tetapi ranah Undang-Undang. 
Penundukan norma yang terdapat di dalam Undang-Undang sektoral jenis infrastruktur yang di-KPBU-kan dengan norma yang terdapat di dalam Perpres yang mengatur KPBU sangat berpotensi dan berpeluang untuk terjadi, mengingat jenis infrastruktur yang dapat di-KPBU-kan merupakan jenis untuk memenuhi kebutuhan umum masyarakat. Dari simpulan di atas, bahwa untuk menghindari deviasi dari Undang-Undang No 12 tahun 2011 tentang pembentukan peraturan perundangundangan terkait penundukan norma yang lebih tinggi kepada norma yang lebih rendah dalam tataran implementasi terkait sistem KPBU ini, sudah seharusnya para pembentuk undang-undang mulai melakukan konsepsi-konsepsi akan pengaturan KPBU di tahap undang-undang, agar tidak menimbulkan potensi-potensi pelanggaran dari sistem perundangundangan di Indonesia.

\section{DAFTAR PUSTAKA}

Asshiddiqie, J. (2006). Hukum Acara Pengujian Undang-Undang. Sekretariat Jenderal dan Kepaniteraan Mahkamah Konstitusi Republik Indonesia.

Attamimi, H. S. (1990). Peranan Keputusan Presiden Republik Indonesia Dalam Penyelenggaraan Pemerintahan Negara: Suatu Studi Analisis Mengenai Keputusan Presiden Yang Berfungsi Pengaturan Dalam Kurun Waktu Pelita I-Pelita IV. Universitas Indonesia.

Guritno, S. B. ; P. D. (2012). Komitmen Pemerintah Dalam Percepatan Penyediaan Infrastruktur di Indonesia. In Bunga Rampai Pengelolaan Risiko Fiskal: Kumpulan Hasil Kajian Tahun 2011-2012 (pp. 131-132). https://www.kemenkeu.go.id/sites/defau lt/files/komitmen pemerintah. dalam percepatan pembangunan infrastruktur di indonesia.pdf

Hadjon, P. M. (1998). Tentang Wewenang Pemerintahan (bestuurbevoegdheid). Pro Justitia, 16(1).
Indera, B. P. (2011). PPP Policy and Regulation in Indonesia.

Peraturan Presiden tentang Kerjasama Pemerintah dan Badan Usaha Dalam Penyediaan Infrastruktur, (2015).

Indrati, M. F. (2007). Ilmu perundangundangan: Jenis, Fungsi dan Materi Muatan. Kanisius.

Keliat, M.; A. V.; F. A. (n.d.). Pembangunan Infrastruktur di Indonesia dan Peran G-20. Global Dan Strategies, $8(1)$.

Kementrian Koordinator bagian Perekonomian. (2010). Kerjasama Pemerintah Dan Swasta (KPS). Kementrian Koordinator bagian Perekonomian.

Maryaningsih, N.; O. H.; M. S. (2014). Pengaruh Infrastruktur Terhadap Pertumbuhan Ekonomi di Indonesia. Buletin Ekonomi Moneter Dan Perbankan.

https://www.google.com/url?sa=t\&rct=j $\& \mathrm{q}=\&$ esrc $=$ s\&source $=$ web $\& \mathrm{~cd}=1 \& \mathrm{cad}$ $=$ rja \&uact $=8 \& v e d=2$ ahUKEwin_Im 8 HhAhU38nMBHTuTBW4QFjAAegQI AhAC\&url=https $\% 3 \mathrm{~A} \% 2 \mathrm{~F} \% 2 \mathrm{Fwww} . b i$ .go.id\%2Fid\%2Fpublikasi\%2Fjurnaleko nomi $\% 2$ Fdocuments $\% 2$ Fpengaruh $\% 25$ 20infrastruktur $\% 2520$ terhadap $\% 2520$ pe rtumbuhan $\% 2520$ ekonomi\%2520indon esia.pdf\&usg=AOvVaw20zL71vzD H1 EHm3VDbZmo

McEown, C. (2009). Civil Legal Needs Research Report: 2nd Edition.

Pamungkas, B. T. (n.d.). Pengaruh Infrastruktur. Retrieved February 16, 2019 , from https://www.google.com/url?sa $=$ t\&rct=j $\& \mathrm{q}=\&$ esrc $=$ s \& source $=$ web \&cd $=9 \& \mathrm{cad}$ $=$ rja\&uact $=8 \&$ ved $=2$ ahUKEwi08b 2 wy 8 DgAhUHQo8KHRaqDTMQFjAIegQI

ARAC\&url=http $\% 3 \mathrm{~A} \% 2 \mathrm{~F} \% 2$ Flontar.ui .ac.id\%2Ffile\%3Ffile\%3Ddigital\%2F 12 5998-6699-Pengaru\%2520infrastrukturLiteratur.pdf\&usg=AOvVaw0Vza0M45 


\section{FoRSUllkcKPpw}

Rifai, B. (2014). Implementasi Kerja Sama Pemerintah dan Swasta Dalam Pembangunan Infrastruktur Sektor Air Minum di Indonesia. Jurnal Ekonomi Dan Pembangunan, 22(2). https://media.neliti.com/media/publicati ons/201052-implementasi-kerja-samapemerintah-dan-s.pdf

Rifai, B. (2016). Kendala Implementasi Kerja Sama Pemerintah Swasta (Kps) Kelistrikan Dan Kebutuhan Perbaikan Kebijakan. Jurnal Ekonomi Dan Pembangunan, 24(1). https://media.neliti.com/media/publicati ons/200960-kendala-implementasi-pppkelistrikan-dan.pdf 2

Widyastuti, R. A. Y. (2018). Anggaran Infrastruktur 2019 Naik Jadi 420, 5 T, Ini Rinciannya. https://bisnis.tempo.co/read/1117867/an ggaran-infrastruktur-2019-naik-jadi-rp4205-t-ini-rinciannya/full\&view $=$ ok

Yulianto, I. (2014). Peranan Keputusan Presiden Republik Indonesia Dalam Penyelenggaraan Pemerintahan Negara. Jurnal Ilmiah Fenomena, 12(1), 1180. 